\title{
Nitrogen and phosphorus fertilization of improved varieties for enhancing phenological traits of wheat
}

\author{
Shazma Anwar ${ }^{1}$, Israeel ${ }^{1}$, Babar Iqbal $^{1 *}$, Asad Ali Khan ${ }^{1}, \operatorname{Imran}^{1}$, \\ Wajid Ali Shah' ${ }^{2}$, Mohammad Islam¹, Wajid Ali Khattak ${ }^{1}$, \\ Ikramullah $^{1}$, Wasim Akram ${ }^{1}$ and Wasim Abbas ${ }^{1}$ \\ 1. Department of Agronomy, University of Agriculture, Peshawar, Pakistan \\ 2. Department of Agronomy, Bacha Khan University, Charsadda, Pakistan \\ *Corresponding author's email: agronomist19388@yahoo.com \\ Citation \\ Shazma Anwar, Israeel, Babar Iqbal, Asad Ali Khan, Imran, Wajid Ali Shah, Mohammad Islam, Wajid Ali \\ Khattak, Ikramullah, Wasim Akram and Wasim Abbas. Nitrogen and phosphorus fertilization of improved \\ varieties for enhancing phenological traits of wheat. Pure and Applied Biology. Vol. 5, Issue 3, pp511-519. \\ http://dx.doi.org/10.19045/bspab.2016.50065
}

\begin{tabular}{llll}
\hline \hline Received: 04/01/2016 & Revised: 25/05/2016 & Accepted: 02/06/2016 & Online First: 17/06/2016 \\
\hline \hline
\end{tabular}

\section{Abstract}

A field experiment was conducted at New Developmental Farm, The University of Agriculture Peshawar during rabi 2012-2013 to study the effect of $\mathrm{N}$ and $\mathrm{P}$ fertilization of improved varieties for enhancing yield and yield components of wheat varieties. Randomized Complete Block (RCB) Design with split plot arrangement having three replications was used. A sub plot size of $12 \mathrm{~m}^{2}$ having ten rows of $4 \mathrm{~m}$ length was used. $\mathrm{N}$ levels (100, 125 and $\left.150 \mathrm{~kg} \mathrm{ha}^{-1}\right)$ and $\mathrm{P}$ levels $\left(60,90\right.$ and $\left.120 \mathrm{~kg} \mathrm{ha}^{-1}\right)$ were applied to the main plots and wheat varieties (Siran-2010 and Atta-Habib) were assigned to the sub plots and one control having no $\mathrm{N}$ and $\mathrm{P}$ was maintained in main plot treatment. All of the phosphorus and half of the nitrogen were applied at sowing time. The remaining $\mathrm{N}$ was applied at tillering stage. The results of the experiment showed that maximum days to anthesis (137), days to maturity (167), number of leaves tiller ${ }^{-1}(6)$, leaf area tiller $^{-1}\left(117 \mathrm{~cm}^{2}\right)$ and leaf area index (4.38) were produced by Siran-2010 while maximum plant height $(98 \mathrm{~cm})$ was maintained by Atta-Habib. Maximum leaf area index (4.64), were produced by $125 \mathrm{~kg} \mathrm{~N} \mathrm{ha}^{-1}$ while nitrogen application at the rate of $150 \mathrm{~kg} \mathrm{ha}^{-1}$ took maximum days to anthesis (140), days to maturity (170), number of leaves tiller-1 (6), leaf area tiller-1 $\left(121 \mathrm{~cm}^{2}\right)$, non-productive tillers $\mathrm{m}^{-2}(19)$ and plant height $(100 \mathrm{~cm})$. Phosphorus application at the rate of $90 \mathrm{~kg} \mathrm{ha}^{-1}$ produced highest leaves tiller-1 (6), leaf area tiller-1 $\left(121 \mathrm{~cm}^{2}\right)$ and leaf area index (4.61). Phosphorus level of $120 \mathrm{~kg} \mathrm{ha}^{-1}$ produced maximum non-productive tillers $\mathrm{m}^{-2}$ (19) and plant height $(100 \mathrm{~cm})$. Fewer days to anthesis (130) and maturity (160) were taken by control plots. It is concluded that wheat variety Siran-2010 produced better phonological traits when treated with $125 \mathrm{~kg} \mathrm{~N} \mathrm{ha}^{-1}$ and $90 \mathrm{~kg} \mathrm{P} \mathrm{ha}^{-1}$.

Key words: Wheat (Triticum aestivum L.); Varieties; Nitrogen; Phosphorus; Penological traits

Introduction

Wheat (Triticum aestivum L.) is the major crop among the cereal in the world and it has been playing a vital role in cultural and economic development since immemorial time. Wheat is known as the king of cereal.
It has greater significance in Pakistan in preventing food demand of the people [1, 2]. Wheat is the basic staple food of Pakistan. Wheat grain contains $12 \%$ protein and provides about $73 \%$ calories [3]. Wheat grains can be directly or 
indirectly used as human food and its straw is used as animal feed. In Pakistan the total area under cultivation of wheat crop was 8.9 million ha, that produce 25.21 million tons of food grain with mean production of $2833 \mathrm{~kg} \mathrm{ha}^{-1}$, while in KPK wheat is cultivated over an area of about 0.72 million ha, which produce 1.11 million tones with average production of $1595 \mathrm{~kg}$ $\mathrm{ha}^{-1}$ [4]. The leading producer of wheat in Pakistan is Punjab. In KPK, more wheat is grown in barani $(61 \%)$ than irrigated area (39\%). As compared to others developing countries wheat production in Pakistan is very low. Quality production and improvement in yield can be achieved by use of balanced nutrient application especially NPK to improved varieties of wheat crop [5]. Besides grain, wheat straw (bhossa) can also be used as roughage for livestock. In order to get highest grain yield selection of the best suited variety is very important. Cultivars are selected on the basis of various characteristics such as straw strength, grain quality and climatic adaptability etc.

Fertilizer application at proper time in balance proportion with proper method of application gave better impact on crop productivity [6]. $\mathrm{N}$ is essential for growth, protein synthesis, vigorous vegetative growth, chlorophyll and deep green color. Nitrogenous fertilizers are used by the farmers in much larger amount than any other fertilizer. This is because plants needed nitrogen in much larger amount than any other nutrient. Moreover our soil is deficient in this most demanding nutrient. On world basis nitrogen application is about 80 million tons [7]. To meet the increasing demand of food for increasing population of the world developing countries apply more and more fertilizers. In 2012 the world population will be more than eight million [8]. However, the fertilizer $\mathrm{N}$ efficiency tends to be low in this system [9].

The chemical fertilizers are the most important source of the readily available nitrogen for the crop growth. Due to the greater availability [10] and crucial input for enhancing crop productivity [11]. $\mathrm{N}$ is a vital part of modern technology for enhancing crop productivity. Nitrogen is one of the major limiting elements for crop growth and development [12]. However effective $\mathrm{N}$ management presents greater challenge to the farmers than other fertilizer nutrients [13]. The availability of $\mathrm{N}$ can be enhanced by its proper time of application, and better strategies to increase crop production. Application of $\mathrm{N}$ improves various growth parameters like fertile tillers $\mathrm{m}^{-2}$ [14], grain yield [15], thousands grain weight [16], more productive tillers [17]. Different nitrogen and phosphorus levels significantly effect the agronomic parameters like, plant height, grain spike, thousand grain weight and root biomass [18].

Phosphorus is essential for many physiological processes, such as storage of energy and its transfer, respiration, photosynthesis, cell division and cell enlargement etc. Phosphorous is involved in the synthesis of energy rich phosphate compound such as adenosine triphosphat (ATP) and adenosine diphosphat (ADP) which derive various biochemical reactions within the plant. Phosphorus role in plant is not limited to metabolic reactions. Phosphorus is a structural component of nucleic acid (DNA, RNA) nucleotide, phospholipids and phosphoprotiens. The movement of applied phosphatic fertilizer in soil is just only 3-4 cm. Consequently, it is hardly available to the extent of $15-20 \%$ to the plant. The rest goes to waste from immediate crop being fixed in soil [19]. Phosphorus application at proper time, in optimum quantity through proper method of application is essential to increase crop production and its sustainability [20].

Phosphorous deficiency in the soil reduced crop response to nitrogen [21]. Crop required proper amount of phosphorus for the initiation of leaves and florets primomordial [22]. Whenever a plant breeder develops a new variety it is very important to find out the production 
technology of that variety especially with reference to the requirement of $\mathrm{N}$ and $\mathrm{P}$ as the nutritional requirement of different variety of the same species may vary due to agro-climatic conditions of the region and their yield potential [23]. Phosphorous is an important element that impacts on zinc uptake, as by increasing phosphorous level in soil zinc uptake by plant is reduced [24]. The rate and form of $\mathrm{N}$ and $\mathrm{P}$ fertilizers can effect plant growth response to mycorrhizal inoculation. The basic role of commercial fertilizer is to enhance crop productivity but the greatest problem is the minimum use of phosphatic fertilizer in obtaining maximum crop production than nitrogenous fertilizer [25].

With reference to the important role of $\mathrm{N}$ and $\mathrm{P}$ in crop productivity, this research study was planned to evaluate the effect of various phosphorous and nitrogen levels on phenology of wheat varieties.

\section{Materials and methods}

An experiment on nitrogen and phosphorus fertilization of improved varieties for enhancing phonological traits of wheat was carried out at New Developmental Farm, The University of Agriculture, Peshawar during winter season 2012-2013. The experiment was arranged in a Randomized Complete Block Design (RCBD) with three replications in split plot arrangement. Size of the sub plots was $4 \times 3 \mathrm{~m}^{2}$. Seed rate of $120 \mathrm{~kg} \mathrm{ha}^{-1}$ was used. Urea and SSP fertilizers were used as $\mathrm{N}$ and $\mathrm{P}$ sources respectively. All of the $\mathrm{P}$ and half of the $\mathrm{N}$ fertilizers were applied at sowing. The rest of the $\mathrm{N}$ was applied at tillering stage. One control having no $\mathrm{N}$ and $\mathrm{P}$ was maintained in main plot treatment. The experiment was consisted of treatments which are nitrogen levels and phosphorus levels which are assigned to Main plots and levels are $\mathrm{N}_{1}$ $\left(100 \mathrm{~kg} \mathrm{ha}^{-1}\right), \mathrm{N}_{2}\left(125 \mathrm{~kg} \mathrm{ha}^{-1}\right), \mathrm{N}_{3}(150 \mathrm{~kg}$ $\left.\mathrm{ha}^{-1}\right)$ where $\mathrm{P}$ levels are $\mathrm{P}_{1}\left(60 \mathrm{~kg} \mathrm{ha}^{-1}\right), \mathrm{P}_{2}$ $\left(90 \mathrm{~kg} \mathrm{ha}^{-1}\right), \mathrm{P}_{3}\left(120 \mathrm{~kg} \mathrm{ha}^{-1}\right)$. Subplot included wheat varieties which are $\mathrm{V}_{1}$ (Siran-2010) and $\mathrm{V}_{2}$ (Atta-Habib). Data was recorded on parameters which are days to anthesis, days to physiological maturity, number of leaves tiller ${ }^{-1}$, leaf area tiller ${ }^{-1}$ $\left(\mathrm{cm}^{2}\right)$, leaf area index, non productive tillers $\mathrm{m}^{-2}$ and plant height $(\mathrm{cm})$. In each sub plot three rows of one meter length were selected randomly to count tillers $\mathrm{m}^{-2}$ and change accordingly to tillers $\mathrm{m}^{-2}$. Data on days to anthesis in each sub plot was taken by counting days from sowing date to the date till $70-80 \%$ plant produced anthesis. Days to PM were counted from sowing date to the date when 70 to $80 \%$ physiological maturity occurred in each sub plot. At anthesis stage ten tillers were randomly selected from three central rows in each sub plot. All the leaves were detached, counted and averaged to obtained number of leaf tiller $^{-1}$. The following formula was used to measure leaf area tiller ${ }^{-1}$.

Leaf area tiller-1 $\left(\mathrm{cm}^{2}\right)=$ Leaf area of all leaves Number of tillers

LAI at anthesis stage in each sub plot was calculated by the following formula.

LAI $=\left(\right.$ Leaf area tiller $\left.{ }^{-1}\right) \mathrm{x}\left(\right.$ Number of tiller $\left.\mathrm{m}^{-2}\right)$

Tillers with un-productive spikes were counted from three randomly selected central rows in each sub plots and changed to spikes $\mathrm{m}^{-2}$ accordingly. Spikes $\mathrm{m}^{-2}$ was recorded by counting spikes in three randomly selected central rows in each sub plots and changed to productive tillers $\mathrm{m}^{-2}$ accordingly. Plant height was measured by measuring height of plant by meter rod including the awns. Method applicable to the randomized complete block design (split-plot arrangement) was used for statistical analysis of the recorded data. For mean comparison in case of significant difference least significant difference (LSD) test at $5 \%$ level of significance was used [26].

\section{Results}

\section{Days to anthesis}

The effect of phosphorus and nitrogen on days to anthesis is reported in table 1 . Statistical analysis of the data showed that nitrogen, phosphorus, varieties and $\mathrm{N} \times \mathrm{P}$ significantly $(\mathrm{P} \leq 0.05)$ affected number of days to anthesis. Increasing rates of nitrogen resulted in more days taken to anthesis. Higher days to anthesis (140) 
were recorded in plots received $150 \mathrm{~kg} \mathrm{~N}$ $\mathrm{ha}^{-1}$ and fewer days to anthesis (130) were taken by control plots. Unlike $\mathrm{N}$ increasing $P$ rates resulted in decreased number of days to anthesis. More days to anthesis (138) were counted in plots received $60 \mathrm{~kg}$ $\mathrm{P} \mathrm{ha}^{-1}$ while minimum (130) were counted in control plots. In case of $\mathrm{N} x \mathrm{P}$ interaction
$\mathrm{N}$ and $\mathrm{P}$ showed antagonistic effects i.e. increasing $\mathrm{N}$ rate increased days to anthesis while increasing $\mathrm{P}$ rate decreased days to anthesis. Between varieties maximum days to anthesis (137) were taken by Siran-2010 while less number of days to anthesis (129) was recorded for Atta-Habib.

Table 1. Days to anthesis, days to maturity, no of leaves tiller $^{-1}$, leaf area tiller-1, leaf area index, no of productive tillers, plant height of wheat varieties as affected by nitrogen and phosphorus fertilization

\begin{tabular}{|c|c|c|c|c|c|c|c|}
\hline Treatment & $\begin{array}{l}\text { Days to } \\
\text { anthesis }\end{array}$ & $\begin{array}{l}\text { Days to } \\
\text { maturity }\end{array}$ & $\begin{array}{l}\text { No. of } \\
\text { leaves } \\
\text { tilles }^{-1} \\
\end{array}$ & $\begin{array}{c}\text { Leaf area } \\
\text { tiller }^{-1}\end{array}$ & $\begin{array}{l}\text { Leaf area } \\
\text { index }\end{array}$ & $\begin{array}{c}\text { Non- } \\
\text { productive } \\
\text { tiller }\end{array}$ & Plant height \\
\hline \multicolumn{8}{|l|}{$\mathbf{N}\left(\mathrm{kg} \mathrm{ha}^{-1}\right)$} \\
\hline 100 & $132 c$ & $162 \mathrm{c}$ & $5 b$ & $106 \mathrm{~b}$ & $3.78 \mathrm{c}$ & $17 b$ & $93 c$ \\
\hline 125 & $135 b$ & $165 \mathrm{~b}$ & $5 b$ & $120 \mathrm{a}$ & $4.64 a$ & $15 \mathrm{c}$ & $98 \mathrm{~b}$ \\
\hline 150 & $138 \mathrm{a}$ & $170 \mathrm{a}$ & $6 a$ & $121 \mathrm{a}$ & $4.48 \mathrm{~b}$ & $19 a$ & $100 \mathrm{a}$ \\
\hline $\operatorname{LSD}(0.05)$ & 0.84 & 0.84 & 0.19 & 1.79 & 0.112 & 0.762 & 0.919 \\
\hline \multicolumn{8}{|l|}{$\mathbf{P}\left(\mathrm{kg} \mathrm{ha}^{-1}\right)$} \\
\hline 60 & $137 \mathrm{a}$ & $167 \mathrm{a}$ & $5 b$ & $110 \mathrm{c}$ & $4.11 \mathrm{c}$ & $16 \mathrm{~b}$ & $94 c$ \\
\hline 90 & $135 b$ & $165 \mathrm{a}$ & $6 a$ & $121 \mathrm{a}$ & $4.61 \mathrm{a}$ & $16 \mathrm{~b}$ & $98 b$ \\
\hline 120 & $134 c$ & $164 c$ & $5 b$ & $116 \mathrm{~b}$ & $4.29 \mathrm{~b}$ & $19 a$ & $100 \mathrm{a}$ \\
\hline LSD (0.05) & 0.84 & 0.84 & 0.19 & 1.79 & 0.112 & 0.762 & 0.919 \\
\hline \multicolumn{8}{|l|}{ Varieties } \\
\hline Siran-2010 & $137 \mathrm{a}$ & $167 \mathrm{a}$ & 5 & $117 \mathrm{a}$ & 4.38 & $16 \mathrm{~b}$ & $96 \mathrm{~b}$ \\
\hline Atta-Habib & $134 b$ & $164 b$ & 5 & $115 b$ & 4.29 & $18 \mathrm{a}$ & $98 \mathrm{a}$ \\
\hline LSD (0.05) & 0.85 & 0.85 & $\mathrm{~ns}$ & 1.388 & $\mathrm{~ns}$ & 0.859 & 1.4 \\
\hline Control & 130 & 160 & 4 & 67 & 1.88 & 21 & 87 \\
\hline \multicolumn{8}{|l|}{ Interaction } \\
\hline $\mathrm{N} \times \mathrm{P}$ & $*$ & $*$ & $*$ & $*$ & $*$ & $*$ & $*$ \\
\hline
\end{tabular}

Mean values of each category followed by different letter (s) are statistically different at $\mathrm{P} \leq 0.05$ using LSD test.

\section{Days to physiological maturity}

The impact of different levels of nitrogen and phosphorus and wheat varieties on days to maturity is reported in table 1 . It was concluded from the statistical analysis of the data that various levels of $\mathrm{N}$ and $\mathrm{P}$ considerably $(\mathrm{P} \leq 0.05)$ affected number of days to maturity of wheat varieties. Only the $\mathrm{N} x \mathrm{P}$ showed significant response on days to maturity while all other interactions i.e. control vs. rest $\mathrm{x}$ variety, $\mathrm{N} x \mathrm{~V}, \mathrm{P} \times \mathrm{V}$ and $\mathrm{N} x \mathrm{P} \times \mathrm{V}$ showed non significant effect on days to maturity. Increasing the rates of nitrogen resulted in increased number of days taken to maturity. Maximum days to maturity (170) was taken by the plots treated with $150 \mathrm{~kg} \mathrm{~N} \mathrm{ha}^{-1}$ and less number of days to maturity (160) was counted in control plots. Unlike $\mathrm{N}$ increasing $\mathrm{P}$ rates resulted in decreased number of days to maturity. More days to maturity (168) were recorded for the plots treated with $60 \mathrm{~kg} \mathrm{P}$ $\mathrm{ha}^{-1}$ while minimum (160) were counted for control plots. Between varieties more days to maturity (167) were taken by Siran-2010 and less number of days to maturity (166) was recorded for Atta-Habib. In case of NP interaction $\mathrm{N}$ and $\mathrm{P}$ showed antagonistic effects i.e. increasing $\mathrm{N}$ rate increased days to maturity while increasing $\mathrm{P}$ rate decreased days to maturity.

Wheat varieties, $\mathrm{N}, \mathrm{P}$ and $\mathrm{N} \quad \mathrm{x} \quad \mathrm{P}$ significantly influenced days to anthesis and maturity. Siran-2010 took more days to 
anthesis and maturity while lower was taken by Atta-Habibb. The difference in days taken to anthesis and maturity may be attributed to the difference of genetic makeup of both these varieties [27]. Applications of $\mathrm{N}$ resulted in delaying anthesis and maturity. With increasing $\mathrm{N}$ levels days to anthesis and maturity also increased. Highest number of days to anthesis and maturity were counted in plots treated with $150 \mathrm{~kg} \mathrm{~N}^{-1}$ while early flowering and maturity occurred in control plots. The late occurrence of anthesis and maturity stages might be due to vagarious and more vegetative growth in fertilized plots [28]. These results also similar with that of [29] who obtained delayed anthesis and maturity at $160 \mathrm{~kg} \mathrm{~N} \mathrm{ha}^{-1}$. Phosphorus application resulted in early flowering and ultimately early maturity. Minimum days to maturity and anthesis were recorded in plots that received $120 \mathrm{~kg} \mathrm{P} \mathrm{ha}^{-1}$. Our results also similar with that of [30] who stated that increasing $P$ rate facilitate earlier reproduction in wheat crop and ultimately early maturity of the crop.

\section{Number of leaves tiller-1}

Statistical analysis of the data revealed that different rates of $\mathrm{N}$ and $\mathrm{P}$ significantly $(\mathrm{P} \leq$ 0.05 ) influenced the number of leaves tiller 1 of wheat varieties (table 1). All the possible interactions except $\mathrm{N}$ x $\mathrm{P}$ showed non significant influence on the number of leaves tiller $^{-1}$. Bothe the varieties (Siran2010 and Atta-Habib) produced same number of leaves tiller ${ }^{-1}$ (5). Nitrogen rate of $150 \mathrm{~kg} \mathrm{ha}^{-1}$ produced highest number of leaves tiller-1 (6). Less number of leaves tiller $^{-1}$ (4) was recorded in control plots. Phosphorus rate of $90 \mathrm{~kg} \mathrm{ha}^{-1}$ produced highest number of leaves tiller ${ }^{-1}$ (6) while minimum (4) were recorded in control plots. In case of $\mathrm{N}$ and $\mathrm{P}$ interactions more number of leaves tillers ${ }^{-1}(6)$ were produced by $\mathrm{P}$ levels of $90 \mathrm{~kg} \mathrm{P} \mathrm{ha}^{-1}$ and $150 \mathrm{~kg} \mathrm{~N} \mathrm{ha}^{-}$ 1

\section{Leaf area tiller-1 $\left(\mathrm{cm}^{2}\right)$}

Data concerning leaf area tiller-1 $\left(\mathrm{cm}^{2}\right)$ of wheat varieties as influenced by $\mathrm{N}$ and $\mathrm{P}$ fertilization is given in table 1. Analysis showed that different levels of $\mathrm{N}$ and $\mathrm{P}$ and $\mathrm{N} x \mathrm{P}$ significantly $(\mathrm{P} \leq 0.05)$ influenced the leaf area tiller ${ }^{-1}$. Varieties also indicated a significant response to different rates of $\mathrm{N}$ and $\mathrm{P}$ for the leaf area tiller ${ }^{-1}$. Variety Siran2010 produced more leaf area tiller ${ }^{-1}$ (117 $\mathrm{cm}^{2}$ ) than Atta-Habib which developed $\left(115 \mathrm{~cm}^{2}\right)$ leaf area tiller-1. A gradual increased in nitrogen resulted in a gradual increased in the leaf area tiller ${ }^{-1}$. More leaf area tiller ${ }^{-1}\left(121 \mathrm{~cm}^{2}\right)$ was measured in plots received nitrogen at the level of $150 \mathrm{~kg} \mathrm{ha}^{-}$ ${ }^{1}$ which is similar with $125 \mathrm{~kg} \mathrm{~N} \mathrm{ha}^{-1}$. P rate of $90 \mathrm{~kg} \mathrm{ha}^{-1}$ resulted in maximum leaf area tiller ${ }^{-1}\left(121 \mathrm{~cm}^{2}\right)$ and lowest $\left(67 \mathrm{~cm}^{2}\right)$ were measured in control plots. In case of $\mathrm{N}$ and $P$ interactions enhancement of leaf area tiller $^{-1}$ increased with increasing $\mathrm{P}$ levels up to $90 \mathrm{~kg} \mathrm{ha}^{-1}$ at all $\mathrm{N}$ levels and then decreased at $125 \mathrm{~kg} \mathrm{P}^{-1}$.

Leaves tiller ${ }^{-1}$ and Leaf area tiller ${ }^{-1}$ were significantly affected by Varieties, N, P and interaction between $\mathrm{N}$ and $\mathrm{P}$ while the rest of interactions showed non significant results. Maximum number of leaves tiller ${ }^{-1}$ and leaf area tiller $^{-1}$ were produced by Siran-2010 than Atta-Habib. Minimum number of leaves tiller ${ }^{-1}$ and leaf area tiller were produced by control plots. This might be attributed to the inherent characteristics of both these varieties and other ecological factors. [31] reported similar result. Nitrogen rate of $150 \mathrm{~kg} \mathrm{~N}^{-1}$ produced highest number of leaves tiller ${ }^{-1}$ and leaf area index that was statistically similar to that produced by $125 \mathrm{~kg} \mathrm{~N}^{-1}$. Higher nitrogen rates extended vegetate phase of the crop that result in more leaf area tiller ${ }^{-}$ ${ }^{1}$ and number of leaves tiller ${ }^{-1}$. Our results are supported by [32] who reported maximum leaf area at $120 \mathrm{~kg} \mathrm{~N} \mathrm{ha}^{-1}$. Phosphorus application significantly affected leaves tiller ${ }^{-1}$ and leaf area tiller ${ }^{-1}$. Phosphorus level of $90 \mathrm{~kg} \mathrm{P} \mathrm{ha}^{-1}$ produced maximum number of leaves tiller ${ }^{-1}$ and leaf area tiller ${ }^{-1}$ and minimum number of leaves and leaf area tiller $^{-1}$ were produced by control plots. [27] reported similar result and stated that $\mathrm{P}$ deficiency decrease leaf 
area by producing smaller and less number of leaves tiller ${ }^{-1}$.

\section{Leaf area index}

Table 1 indicated that nitrogen, phosphorus, varieties and $\mathrm{N} \quad \mathrm{X} \quad \mathrm{P}$ significantly $(\mathrm{P} \leq 0.05)$ affected leaf area index. Highest leaf area index (4.38) was produced by Siran-2010 and lowest leaf area index (4.29) was produced by AttaHabib. Nitrogen rate of $150 \mathrm{~kg} \mathrm{ha}^{-1}$ resulted in highest leaf area index (4.84) while lowest (1.88) were recorded in control plots. Highest leaf area index (4.61) was produced by $90 \mathrm{~kg} \mathrm{P} \mathrm{ha}^{-1}$, and lowest (1.88) were measured in control plots. In case of nitrogen and phosphorus interactions enhancement of leaf area index increased with increasing $\mathrm{P}$ levels upto $90 \mathrm{~kg} \mathrm{ha}^{-1}$ at all levels of $\mathrm{N}$ and then decreased at $120 \mathrm{~kg}$ $\mathrm{P} \mathrm{ha}^{-1}$. Wheat varieties, $\mathrm{N}, \mathrm{P}$ and interaction between $\mathrm{N}$ and $\mathrm{P}$ significantly affected leaf area index the rest of the interaction showed non significant results. Siran-2010 produce highest leaf area index than Atta-Habib. The difference in genetic makeup [33] and suitability of the variety to ecological condition might the reason for highest leaf area index. Higher leaf area index (LAI) were produced by the plots treated with 125 $\mathrm{kg} \mathrm{N} \mathrm{ha}^{-1}$ while lowest leaf area index (LAI) were recorded in control plots. Similar results were reported by [34] who got higher LAI at $120 \mathrm{~kg} \mathrm{~N} \mathrm{ha}^{-1}$. Maximum leaf area index (LAI) maintained by the plots received $90 \mathrm{~kg} \mathrm{P} \mathrm{ha}^{-1}$ and minimum was recorded in control plots. [25] found $108 \mathrm{~kg}$ $\mathrm{P} \mathrm{ha}^{-1}$ to be the best level for the production of maximum LAI.

\section{Non-productive tillers $\mathbf{m}^{-2}$}

Data presented in table 1 revealed that $\mathrm{N}$ and $\mathrm{P}$ rates significantly $(\mathrm{P} \leq 0.05)$ influenced non productive tillers $\mathrm{m}^{-2}$ of wheat varieties. All possible interactions beside $\mathrm{N} \times \mathrm{P}$ remained non significant. Wheat variety Atta-Habib produced maximum non productive tillers $\mathrm{m}^{-2}$ (18) while minimum (16) were produced by Siran-2010. Control plots produced maximum non productive tillers $\mathrm{m}^{-2}$ (21). Increasing $\mathrm{N}$ rates increased the number of non productive tillers. More non productive tillers $\mathrm{m}^{-2}(19)$ was recorded in plots treated by $150 \mathrm{~kg} \mathrm{~N} \mathrm{ha}^{-1}$ while lowest (15) at 125 $\mathrm{kg} \mathrm{N} \mathrm{ha}^{-1}$. Maximum non productive tillers $\mathrm{m}^{-2}$ (19) were produced by $125 \mathrm{~kg} \mathrm{P} \mathrm{ha}^{-1}$ while $\mathrm{P}$ rate of $90 \mathrm{~kg} \mathrm{P} \mathrm{ha}{ }^{-1}$ produced minimum unproductive tillers $\mathrm{m}^{-2}$ (16) that was statistically at par with $60 \mathrm{~kg} \mathrm{P} \mathrm{ha}{ }^{-1}$ (16). In case of NP interactions non productive tillers $\mathrm{m}^{-2}$ increased with increasing levels of $\mathrm{N}$ with $\mathrm{P}$. Varieties, nitrogen, phosphorus and NP interaction considerably $(\mathrm{P} \leq 0.05)$ influenced number of non-productive tillers $\mathrm{m}^{-2}$. Highest number of non-productive tillers $\mathrm{m}^{-2}$ was maintained by Atta-Habib while lowest by Siran-2010. The variation in nonproductive tillers $\mathrm{m}^{-2}$ may be due to the genetic variations of these two cultivars. These results are similar with that of [27]. Highest number of non-productive tillers $\mathrm{m}^{-2}$ was maintained by control plots while minimum was recorded at $125 \mathrm{~kg} \mathrm{~N} \mathrm{ha}^{-1}$. This is supported by [35] who reported that increasing $\mathrm{N}$ rate decrease non-productive tillers $\mathrm{m}^{-2}$. Highest number of nonproductive tillers $\mathrm{m}^{-2}$ were produced by control plots while lowest were found at 90 $\mathrm{kg} \mathrm{P} \mathrm{ha}{ }^{-1}$ that is at par with $60 \mathrm{~kg} \mathrm{P} \mathrm{ha}{ }^{-1}$. Higher $\mathrm{P}$ rates enhanced tillers survival, emergence and yield, especially for secondary tillers [36].

\section{Plant height (cm)}

Table 1 represents data regarding the effect of N, P and V on plant height. Analysis of data showed that different levels of N, P and $\mathrm{NP}$ interaction significantly $(\mathrm{P} \leq 0.05)$ affected plant height of wheat varieties. With each additional increment of $\mathrm{N}$ plant height increased. Highest plant height (100 $\mathrm{cm})$ was measured in plots with nitrogen rate of $150 \mathrm{~kg} \mathrm{~N} \mathrm{ha}^{-1}$ and lower plant height $(89 \mathrm{~cm})$ was measured in control plots. Phosphorus rate of $120 \mathrm{~kg} \mathrm{ha}^{-1}$ produced tallest plants $(100 \mathrm{~cm})$ while minimum $(89$ $\mathrm{cm})$ were recorded in control plots. Between the varieties tallest plants $(98 \mathrm{~cm})$ were produced by wheat variety Atta-Habib followed by Siran-2010. Regarding interactive effect of nitrogen and 
phosphorus plant height increased linearly with increasing both $\mathrm{N}$ and $\mathrm{P}$ levels. Different levels of N, P and NP interaction considerably affected plant height of wheat varieties. Tallest plants were produced by Att-Habib than Siran-2010. The possible reason for this might be the difference in genetic combination of these two varieties. Considerable difference in plant height of different wheat varieties were also reported by [37]. $\mathrm{N}$ and $\mathrm{P}$ rate of $150 \mathrm{~kg} \mathrm{~N} \mathrm{ha}^{-1}$ and $120 \mathrm{~kg} \mathrm{P} \mathrm{ha}{ }^{-1}$ produced tallest plants. With increasing $\mathrm{N}$ rates plant height also increased. This is supported by [29] who got maximum plant height at $\mathrm{N}$ rate of 160 $\mathrm{kg} \mathrm{ha}{ }^{-1}$. Increasing $\mathrm{P}$ level considerably increase plant height. These results are in agreement with [38] who stated that with increasing $\mathrm{P}$ rate plant height increased. Similarly [30] reported maximum plant height at $120 \mathrm{~kg} \mathrm{P} \mathrm{ha}^{-1}$.

\section{Conclusion and recommendation}

It was concluded from the experiment that wheat variety Siran-2010 performed better than Atta-Habib in terms of phenology. Nitrogen application at the rate of $150 \mathrm{~kg}$ $\mathrm{ha}^{-1}$ produced better phonological traits. Phosphorus application up to $90 \mathrm{~kg} \mathrm{ha}^{-1}$ showed better impact on growth and phenology. Wheat variety Siran-2010 is recommended for general cultivation due to its better growth performance. Phosphorus level of $90 \mathrm{~kg} \mathrm{ha}^{-1}$ and Nitrogen level of 150 $\mathrm{kg} \mathrm{ha}^{-1}$ is recommended for better growth and phenology of wheat.

\section{Authors' contribution}

Conceived and designed the experiments: $\mathrm{S}$ Anwar \& Israeel, Performed the experiments: Israeel, B Iqbal, M Islam \& WA Khattak, Analyzed the data: S Anwar \& Israeel, Contributed reagents/ materials/ analysis tools: AA Khan, Imran, WA Shah, Ikramullah, W Akram \& W Abbas, Wrote the paper: S Anwar \& B Iqbal.

\section{References}

1. Malik MA, Irfan M, Ahmed ZI \& Zahoor F (2006). Residual effect of summer grain legumes on yield and yield components of wheat (Triticum aestivum L.). Pak J Agric Agril Engg Vet Sci 22: 9-11.

2. Tuino SD, Korejo MN, Jarwar AD \& Waggan MR (2006). Studies on indigenous and exotic weed competition in wheat. PakJ Agric Engg Sci 22:1.

3. Heyan EG (1987). Wheat and wheat improvement. $2^{\text {nd }}$ ed.Madison, Wisconsin, USA.

4. MINFA (2011). Agricultural statistics of Pakistan. Govt. of Pakistan, Islamabad.

5. Ahmed N \& Rashid M (2004). Fertilizer and their use in Pakistan. Govt. of Pak Plan and Dev Div NFDC, Islamabad.

6. Alam SM, Shah SA, Latif A \& Iqbal Z (2002). Performance of some wheat varieties to fertigation applied phosphorus sources. Pak J Soil Sci 11(2):123-125.

7. FAO (1990). Fertilizer yearbook 1990. Rome.

8. Sadik N (1992). The state of world population. New York, NY, USA. United Nations Population Fund P. 3845.

9. Byerlee D \& Siddiq AA (1994). Has the green revolution been maintained? The quantitative impact of the seed-fertilizer revolution in Pak. Revisited. World Devel 22: 1345-1361.

10. Ahmad N, Rashid M \& Vaes AG (1996). Fertilizer efficiency. Int: (Eds):N. Fertilizers and their use in Pakistan. NFDC Pub. Islamabad. P.166.

11. Geleto T, Tanner DG, Mamo $\mathrm{T} \&$ Gebeyenu G (1995). Response of rainfed bread and Durum wheat to source, level and timing of nitrogen fertilizer on yield and yield components of two Ethiopian varieties. Common Soil Sci and Pl Anal 26(12): 1773-1794.

12. Heichel GH \& Barnes DK (1984). Opportunities for meeting crop nitrogen needs from symbiotic nitrogen fixation. 49-59. In :( Ed.): D.F. Bezdicek et al., Organic farming Current technology and its role in sustainable agriculture. 
Special publication. No. 46. ASA, Madison, WI.

13. Olson RV \& Kurtz LT (1982). Crop nitrogen requirement, utilization and fertilization. p. 567-604. Int: (Ed.): F. J. Stevenson. Nitrogen in agricultural soils. ASA, Madison, WI.

14. Behera UK \& Sharm KC (1991). Effect of irrigation in fertility levels on the yield of wheat in Tarai. Orissa J Agric (1- 2): 130-2.

15. Singh VP \& Uttam SK (1992). Response of wheat cultivars to different nitrogen levels under sown conditions. Crop 5: 82-6.

16. Warraich EA, Ahmad N, Basra SMA \& Afzal I (2002). Effect of nitrogen on source-sink relationship in wheat. Int $J$ Agric Bio 4: 300-02.

17. Wilhelm WW (1998). Dry matter partitioning and leaf area of winter wheat grown in a long term fallow tillage comparisons in U.S. Central Great Plans. Soil and Tillage Res. 49: 49-56.

18. Ahmed S, Jan NE, Khan R, Faridullah \& Din N (2010). Wheat response to Phosphorous under climatic conditions of Juglote Pakistan. Sarhad J Agric 26(2): 229-233.

19. Camargo C, Felicio JC, Freitas JG \& Paulo S (2000). Evaluation of wheat cultivars for phosphorus efficiency on acid soils and in nutrient solution. Ecol Agric and Sus 2: 289-29.

20. Cisse L \& Amar B (2000). The importance of phosphatic fertilizer for increased crop production in developing countries. In: Proceedings of the AFA $6^{\text {th }}$ International Annual conference held on $31^{\text {st }}$ Jan and 2nd Feb. 2000. Cairo, Egypt.

21. Senigagliesi CA, Garcia R, Meria S, Galetto MLR, Defrusos E \& Teves R (1983). Fertilizer application to wheat in the north of province of Buyenos Aires and south of Santafe. Agropecuaria Pergamino. Argentiana. J Field Crop 37(7): 5117-1984.
22. Richards JF, Graham PH \& Eichorn BM (1985). Effect of super phosphate and nitrogen on yield of wheat. New Zealand. J Crop Hort 11: 103-8.

23. Imtiaz M, Shah KH, Khan P, Siddiqui SH, Memon MY \& Aslam M (2003). Response of wheat genotype S1-91195 to increasing $\mathrm{N}$ and $\mathrm{P}$ levels and their ratios under agro-climatic conditions of Sindh. Pak J soil Sci 22: 58-63.

24. Salimpour S, Khavazi M, Nadian H, Besharati H, Miransari M (2010). Enhancing phosphorous availability to canola (Brassica napus L.) using $\mathrm{P}$ solubilizing and sulfur oxidizing bacteria. Aust J Crop Sci 4(5): 330-334.

25. Jiang ZQ, Feng CN, Huang LL, Guo WS, Zhu XK \& Peng YX (2006). Effect of phosphorus application on dry matter production and phosphorus uptake in wheat. Plant Nut And Fert Sci 12(5): 628-634.

26. Steel RGD \& Torrie JH (1980). Principles and procedure of statistics. A biological approach $2^{\text {nd }}$ ed. McGraw Hill Inc. New York.

27. Ahmad A, Mahmood N \& Akhtar B (1997). Effect of different depths of irrigation on the grain yield of promising late sown wheat cultivars. Rachis 16(1-2): 77-80.

28. Khan P, Imilaz M, Aslam M, Shah SK H, Mudinn N, Memon MY, Siddique S (2008). Effect of different nitrogen and phosphorous ratios on the performance of wheat cultivar khirman. Sarhad $J$ Agric P. 24-2.

29. Khalil SK, Khan F, Rehman A, Muhammad F, Amanullah, Khan AZ, Shah MK \& Khan H (2011). Dual Purpose wheat for forage and grain yield in response to cutting, seed rate and nitrogen. Pak J Bot 43(2): 937-947.

30. Hossain N, Khan MB \& Ahmad R. (2008). Influence of phosphorus application and sowing time on performance of wheat in calcareous soils. Int J Agric Bio 10: 709-714.

31. Bisht JK, Kant L \& Srivasta AK (2008). Cutting management of dual purpose 
wheat cultivars; a new approach for increasing fodder availability. Cereal Research Communications 36(1): 177187.

32. Laghari GM, Oad FC, Tunio SD, Gandahi AW, Siddiqui MH, Jagirani AW \& Oad SM (2010). Growth yield and nutrient uptake of various wheat cultivars under different fertilizer regimes. Sarhad J Agric 26(4): 489497.

33. Woyema A, Bultosa G \& Taa A (2012). Effect of different nitrogen fertilizer rates on yield and yield related traits for seven durum wheat cultivars grown at sinana, south eastren Ethopia. Afric $J$ Food Agric nutr Develop 12(3): 60796094.

34. Halikatti SI (1980). Effect of levels, time and method of nitrogen application on growth and yield of wheat (Triticum aestivum L.) under irrigation. MSc Agric Thesis, Univ Agric Sci Dharwad.
35. Bakht J, Shafi M, Zubair M, Khan MA \& Shah Z (2010). Effect of foliar vs. soil application of nitrogen on yield and yield components of wheat varieties. Pak J Bot 42(4): 2737-2745.

36. Fioreze SL, Castoldi G, Pivetta LA, Pivetta LG, Fernandes DM \& Büll LT (2012). Tillering of two wheat genotypes as affected by phosphorus levels. Acta Scientiarum Agric 34(3): 331-338.

37. Munsif F \& Arif M (2011). Effect of planting dates on the potential use of dual purpose wheat cultivars. Ph.D. Thesis. KPK Agric. Univ. Peshawar.

38. Rahim A, Ranjah AM, Rahamtullah \& Waraich EA (2010). Effect of phosphorus application and irrigation scheduling on wheat yield and phosphorus use efficiency. Soil Sci Soc Pak 29(1): 15-22. 